\title{
Guardians of the Hegemonic Structure of Sports? Women's Sports as Perceived by Polish Female Sports Journalists
}

\author{
Natalia Organista \\ Zuzanna Mazur \\ University of Physical Education in Warsaw
}

DOI: http://dx.doi.org/10.18778/1733-8069.16.1.04

\section{Keywords:}

sports journalism,

female sports

journalists, women's

sports, Polish media

\begin{abstract}
The under-representation of media coverage of women's sports has been a long-standing phenomenon, which can also be observed in Poland (Dziubiński, Organista and Mazur 2019; Jakubowska 2015; Kluczyńska 2011). One of the possible reasons for less information on women's sports is a small number of female sports journalists. Due to the lack of Polish research on female sports journalists, the authors of this article aimed at analyzing their beliefs about women's sports and the under-representation of media coverage of women's sports in the Polish media. The analysis has shown that the female journalists perceive women's sports as inferior to men's sports and are not in favor of increasing the amount of information about women's sports. The authors point to the socialization into sport, the professional socialization of the research participants, their minority status in the profession as well as their perception of masculinity, femininity, and professionalism in journalism as possible reasons for the way in which women's sport is perceived by them.
\end{abstract}

Organista Natalia, Ph.D, is working in the Department of Humanities and Social Sciences at the Józef Piłsudski University of Physical Education in Warsaw. Her research has focused on issues of sport and feminism, sports media, sports organizations, and gender inequalities in sport.

\section{Contact details:}

Józef Piłsudski University of Physical Education in Warsaw

Faculty of Physical Education

Department of Humanities and Social Sciences

Marymoncka 34, 00-968 Warszawa

email address: natalia.organista@gmail.com
Zuzanna Mazur, Ph.D, is working as an associate professor in the Department of Pedagogy and Psychology of Physical Culture at the Józef Piłsudski University of Physical Education in Warsaw. Her research interests include social and gender inequalities, images of sportswomen, and social patterns of participation of women in sport and physical culture.

\section{Contact details:}

Józef Piłsudski University of Physical Education in Warsaw Faculty of Physical Education

Department of Pedagogy and Psychology of Physical Culture Marymoncka 34, 00-968 Warszawa email address: zuzanna.mazur@op.pl 
ports $^{1}$ sociologists have been pointing out for decades that sport remains an institution that constructs and sustains certain patterns of masculinity and femininity. It is emphasized that sport strengthens male hegemony in society and traditional relationships between the sexes. Although the massive entrance of women into sport makes gender models redefined and contested, it is believed that changes in the gender order in sports are slower than in other spheres of social life (Cooky, Messner, and Musto 2015). Male dominance in sports can be observed based on the example of media coverages of sports. Examining media coverages is vital, because most sports events nowadays are consumed by the audience exclusively through the media. Although mass media create a specific way of describing sports - one that is based on beliefs prevailing in a given culture - locating sports in the information media creates the impression of objectivity and impartiality of the coverage (Bruce 2013). By broadly covering certain events (men's team sports) and ignoring others (women's sports, disabled sports), the media create a narrative about what is important in sports.

Numerous content analyses of media coverages have shown the underrepresentation of information about women's sports in the USA, Australia (Turner 2014; Billings and Young 2015; Cooky et al. 2015; Schmidt 2018), and Europe (Crolley and Teso 2007; Horky and Nieland 2011; Godoy-Pressland 2014; O'Neill and Mulready 2015), as well as biased descriptions of women's sports and female contestants (Fink and Kensicki 2002; Vincent et al. 2007; Greer, Hardin and Homan 2009; Eagleman 2015; Sherry, Osborne, and Nicholson 2016).

${ }^{1}$ Publication financed from the funds of the University of Physical Education in Warsaw, no. DM-55.
Polish research also shows the inequitable coverage of women's sport compared to men's sports (Kluczyńska 2011; Jakubowska 2013; Dziubiński et al. 2019) and the lack of respectful coverage (Dziubiński et al. 2019). A study by Honorata Jakubowska (2015), conducted as part of the International Sports Press Survey between April and July 2011, showed that in Gazeta Wyborcza, Głos Wielkopols$k i$, and Fakt articles on women's sports specifically accounted for $9 \%$ of all articles on sports. Female journalists wrote only $8 \%$ of articles in the period in question. A study of TV sports news from 2008 showed that $93 \%$ of the total air time was devoted to men's sports (Kluczyńska 2011:390). The four-year survey of Gazeta Wyborcza between 2010 and 2013 showed that $12.5 \%$ of articles were written about women's sports. Female journalists were authors of only 11 out of 2997 articles (Dziubiński et al. 2019).

Janet Fink (2015) reviewed the studies of sports media coverages conducted so far and identified the most frequent differences in the description of women's and men's sports. Female athletes are often described in negative contexts, i.e. their failures and their physical or emotional weakness are pointed out (Vincent et al. 2007; Angelini, MacArthur, and Billings 2012). Media coverages of male competitions are much more enthusiastic and emphasize the extraordinary possibilities of male athletes, while their potential failures are justified with a greater shape of the rivals. Coverages of women's sports are more often mere reports of results and as such tend to be boring (Cooky et al. 2015). In addition, attention is often paid to the physical appearance and out-of-sport roles of female athletes (Fink and Kensicki 2002; Bissell and Duke 2007; Vincent et al. 2007; Sherry et al. 2016). What is more, they are infantilized by being called by their first names or with diminutives [for example Isia - regarding Agnieszka Radwańska or Złotka 
(Darlings) for Polish female volleyball players] (Wensing and Bruce 2003; Crolley and Tesso 2007). When describing women's sports, journalists also use ambivalence, which means that they combine positive descriptions with expressions which undermine the achievements of female athletes (Bruce 2013; Eagleman 2015). Fink also pointed to gender marking, i.e. unnecessary stressing that a sporting event concerns women's sport. This illustrates that men's sports and competitions are considered to be a standard, and women's sports as a deviation from such a norm (Crolley and Tesso 2007). The last difference mentioned by Fink concerns a different way of producing sporting events. Research has shown that media coverages of men's sports events are more advanced (more variations in the viewers' field of vision, more people involved in the production, or more expert opinions on a given sporting event) (Bissel and Duke 2007; Greer et al. 2009). A different type of 'producing' women's sports events makes them perceived as less interesting and worth less attention.

Undoubtedly, images of female athletes in the media are also changing. Toni Bruce (2016) points to the ways of describing female athletes, which are often ignored in the analyses of the differences in the framing of female and male athletes. According to Bruce, more and more frequently, female athletes are treated as serious athletes and role models, and are described only in relation to their professional duties. However, more research is needed in order to determine to what extent these new ways of describing female athletes are becoming a norm, and in which countries and contexts.

\section{Theoretical Assumptions: (Sports) Journalism as a Male Field}

The analyses of journalism and sports journalism conducted in recent decades by feminist media scholars have shown that beliefs about masculinity, femininity, and sports shape journalism as a gendered institution.

When looking for the reasons for the underrepresentation of women's sports in the media, sports media scholars pointed to a small number of female sports journalists (Hardin and Shain 2006; Lapchick 2008; Cooky et al. 2015). The research shows that female sports journalists are a minority group: in the USA, female sports journalists have written only $10.2 \%$ of articles for the last thirty years in the examined press (Schmidt 2018), 11\% in Australia, and 7\% in New Zealand (Strong and Hannis 2007). Similarly, data from Europe indicates a small number of female sports journalists: in Great Britain, they wrote $1.8 \%$ of texts in the analyzed periods of 2012 and 2013 (Franks and O'Neill 2016), 13\% in Switzerland (Schoch and Ohl 2011), and 7\% in the Netherlands (Claringbould, Knoppers, and Elling 2004). It was assumed that the moment female sports journalists reached the 'critical mass', they would gain influence over newsrooms and would be in favor of more (and equitable) coverages of women's sports in the media (Ferguson 1990). This approach was called the "add women and stir" or "body count" idea and was associated with the principles of liberal feminism that cares for equal representation and opportunities for women and men in professional life (de Bruin and Ross 2004; Hardin and Shain 2006). The critics of this assumption argued that even with the increased presence in the profession, female journalists would not be resistant to the long-held practices and assumptions which disfavor female journalists (de Bruin and Ross 2004; Hardin and Shain 2006; Steiner 2012). Moreover, the belief that a greater representation of female journalists would be equivalent to their empowerment and that they would introduce 
the 'feminist agenda' as their professional goal was considered the feminist fallacy (Hardin and Shain 2006). Hence, feminist media scholars have drawn attention to the practices, norms, and values that are characteristic of media organizations that make female journalists 'other' in newsrooms. An inquiry into the processes of emergence of discourses of masculinity, femininity, and professionalism reveals that journalism is not a gender-neutral institution, but, rather, as Marie Hardin and Stacie Shain (2006:324) state, "Professional values in news support 'macho' cultures in newsrooms." Female sports journalists often have to negotiate between conflicting social identities of women and journalists. It was pointed out that the values (objectivity, independence, but also a competition-oriented approach and toughness) underlying journalism are not gender-neutral; instead, they represent masculinize journalism (de Bruin and Ross 2004; Hardin and Shain 2006). In order to be seen as fair and neutral, female journalists need to 'be like men'. At the same time, in order to be accepted in the profession, they have to meet the social expectations of femininity. Therefore, they are expected to be empathetic, committed, and kind (Hardin and Shain 2006). However, these are not the most desirable traits among journalists, which may be one of the reasons why women wait longer for promotion and more often perform only ancillary roles in newsrooms (Chambers, Steiner, and Fleming 2004:72; Whiteside and Hardin 2015). What is more, they are less often assigned to report on the so-called hard news stories (politics, economy, sport) as these are considered to be the most prestigious in journalism. Instead, they are more often assigned to soft news (social affairs, entertainment, art) (North 2016). To be recognized within the profession, female journalists need to adapt to the existing practices and develop "thick skin," a "survival strategy" (Creedon 1998:98) or become "one of the boys" or "honorary men" (Hardin and Shain 2006).

In addition, sport has been considered a male thing for a long time, which is why female sports journalists are experiencing a number of problems. It is difficult for them to gain respect and recognition, and they perform mainly subsidiary and less prestigious tasks. Female sports journalists hardly ever act as hosts in a match studio as well as they do not act as experts or commentators (especially with regard to men's team sports). Much more often, they work 'on the sidelines', doing short interviews with contestants (Chambers et al. 2004:72; Hardin and Shain 2005; 2006). Most often, however, they are TV presenters. Women's positions in a broadcasting job are rarely questioned due to compliance with the cultural beliefs regarding the ability of women to gain the attention of viewers with their attractive physical appearance (Boyle 2006:153-154). They also perform tasks that are rejected by their male colleagues, e.g. they more often provide coverages of women's sports as these are considered less valuable than men's sports (Schmidt 2018). According to Erin Whiteside and Marie Hardin (2015), with their status of a minority group, female journalists try to work more than their male colleagues in order to prove their competence; they try to make their 'visibility' an asset and blend in with their workplace. Gender divisions in sports journalism are illustrated by Deborah Chambers' words when she says that, "Sports news is home of the most intense and historically enduring gender divisions in journalism, in terms of who is permitted to cover which sports as journalists how athletes are covered as well as in terms of which genders are served as audiences" (Chambers et al. 2004:111-112). 


\section{Mapping the Field: Gender Ratios in the Polish Journalism}

The above-mentioned gender divisions in journalism are confirmed by the empirical data. In the part of the research devoted to Poland, both the Global Media Monitoring Project (GMMP 2015a) and the Global Report on the Status of Women in the News Media (2011) point to the existence of a glass ceiling in access to the most prestigious positions in journalism and significantly more frequent examples of presenting soft news by female journalists, with hard news left for male journalists. Despite the fact that there are two associations of journalists operating in Poland, none of them collects data on the number of sports journalists. It is only the results of content analyses performed on sports coverages that provide such information. More hard quantitative data is provided by reports analyzing the general situation of women working as journalists, which is not limited to sports journalism.

The results of the content analysis of sports news presented in three daily newspapers investigated between April and July 2011 showed that female sports journalists had written $8 \%$ of articles (Jakubowska 2015). However, the results of a fouryear study of sports pages in Gazeta Wyborcza in the years 2011-2013 showed that female journalists had written only 3\% of articles (Dziubiński et al. 2019). The data presented below regarding the profession of a journalist indicates that there may be fewer women in sports journalism in Poland than in any other type of journalism.

The world's largest study analyzing the participation of women in the media, the GMMP (2015a), confirmed that both female journalists and women as journalistic sources and subjects of media materials constitute a minority. In Poland, 31\% of reporters were women ( $28 \%$ in the press, $43 \%$ on the radio, and $29 \%$ on TV), while when one combines data on female presenters and reporters into one category, they will achieve significantly smaller differences between the percentages for women and men: $48 \%$ of women and $52 \%$ of men worked for $\mathrm{TV}$, and $57 \%$ of women and $43 \%$ of men worked for the radio; the difference remained significant only for the press, i.e. $28 \%$ of women worked for the press at the time of the study (GMMP 2015a). Only $23 \%$ of the studied materials concerned the situation of women. Women were sources of press materials in the case of $25 \%$ of regional news, $31 \%$ of domestic news, and $26 \%$ of international news. Gender division in hard and soft news is also visible. Only $17 \%$ of female journalists in Poland dealt with a topic related to politics and the government, and 31\% with economics. More often, female journalists dealt with issues related to science and health ( $45 \%$ of media materials), and $42 \%$ of the contents were connected with social and legal issues. Sports-related media materials were added to the 'celebrity, arts, and media' category. Despite the fact that it is usually women who write about celebrities, in Poland most ( $80 \%$ ) of such materials were written by male journalists. Although combining sports with art, media, and celebrity news does not allow for drawing clear-cut conclusions, it is likely that media materials concerning sports the majority of which in Poland is covered by male journalists - caused such a difference in percentages between male and female journalists. What is equally important, 79\% of subjects of the 'celebrity, art, and media' category and sport news were men. When classifying media subjects by the occupation criterion, in $83 \%$ of cases a sportsperson, an athlete, a player, a coach or a referee presented in the Polish media was male (GMMP 2015a). 
When comparing the presented data with the data collected worldwide, it should be stated that female journalists in Poland dealt with topics from the celebrity art and media and sport group less frequently than in Europe and North America. In Europe, $42 \%$ of female journalists dealt with this topic, in North America 32\%, while it was 34\% when summing up the results for all the surveyed countries worldwide (GMMP 2015b, 2015c). Also, more often than in Poland, female journalists in other countries dealt with topics considered to be reserved for men, such as politics and the government $(31 \%$ on a global scale, 30\% in Europe), or economy (39\% on a global scale, 43\% in Europe). Globally, the GMMP confirmed that a glass ceiling is still observable with regard to a reporter's tasks. Only $37 \%$ of news in newspapers, on television, and radio were announced by women. Women were news subjects of media materials in 24\% (GMMP 2015b).

In turn, the Global Report on the Status of Women in the News Media (2011) showed that female journalists were underrepresented at the 'top management' level, where $75 \%$ of positions are occupied by men, with $58.1 \%$ for senior management and 56.2\% for middle management (Nastasia and Nastasia 2013). Just to compare, in other countries of Central and Eastern Europe there are many more women holding managerial positions in journalism: $68.6 \%$ of the senior professional level in Bulgaria, $69.6 \%$ in Romania, and $70.6 \%$ in Lithuania.

\section{Methods}

Due to the lack of Polish research on the opinions of female sports journalists regarding the position of women's sports in the media and their potential ability to change inequitable gender stereotyping and gender-biased coverages in sports media on the whole, a decision was taken to conduct such research. Its main goal was to analyze the beliefs of female sports journalists concerning women's sports and the underrepresentation of coverages of women's sports in the Polish media (Kluczyńska 2011; Jakubowska 2015; Dziubiński et al. 2019). Answers to the following research questions were sought:

RQ1: How do surveyed female journalists perceive women's sports?

RQ2: How do surveyed female journalists assess the results of the content analysis of sports materials in the press?

RQ3: Do surveyed female journalists see the need to promote women's sports in the media?

To that end, eighteen semi-structured individual in-depth interviews with female sports journalists working in television, press, radio, and in on-line journalism were conducted. In order to keep the research anonymous, it was not revealed for which medium the journalists worked for. They were often the only women in sports departments, which is why revealing such information would make it possible to identify them. The chosen qualitative method allowed the researchers to accurately depict the significance attributed to women's sports by the respondents and to present their beliefs about the importance of gender differences in sport.

The interviewees had worked in sports journalism for at least four years. Seven of them have worked for more than ten years, another seven between five and ten years, and four have begun their fifth year of work. Their average age was 33.5. In addition to their usual duties, the journalists occasionally performed editorial and reporting tasks, but none of them was 
the editor-in-chief of the sports department when the study was conducted. None of them had previously dealt with another type of journalism either. Eleven respondents indicated that they worked in television, three for the press, six in new media, and one in radio. A greater number of indications against the number of respondents results from the fact that journalists sometimes worked in several places or performed tasks for both new media and traditional mass media (television, press, radio). After obtaining consent to conduct the survey from the first participant, volunteers were further sought for the purpose of using the snowball method.

The female sports journalists were asked about their perception of women's sports and their status, as well as the method of implementing, commenting on, and describing sports events concerning both women and men. They were also presented the content analyses of sports media in Poland regarding the amount of space and the way of describing women's and men's sports, as well as they were asked to comment on the results. The interviews took from forty minutes to one hour; they were transcribed verbatim and then analyzed several times for any patterns and frequently emerging topics. The results were divided into three parts that corresponded with the answers to the afore-mentioned research questions. The respondents' statements used in this article have been translated from Polish by the authors.

\section{Results}

\section{The Higher Status of Men's Sports}

The researched female sports journalists clearly pointed to a higher status of men's sports. The claim that men's sport is superior to women's sport was not only due to the knowledge of the journalists' preferences or the profitability of publishing specific contents in the media, but also due to their own beliefs. The female sports journalists declared that they themselves preferred to watch men's sports and do not value women's sports highly.

When I watch tennis it's men's tennis, when I turn on the TV and it's women's tennis I turn it off because you can't watch it. It's the same with volleyball. (interview 7)

I feel closer to men's sports. Men's sport is number one. It's more attractive to the eye than women's sport. (interview 14)

I really dislike [women's sports] and it's not an isolated opinion. Volleyball or tennis performed by men are real sports and in the case of women it's a kind of failure. (interview 5)

Only two out of eighteen female sports journalists clearly stated that they respected women's sports and treated it equally with men's sports. The respondents often compared women's and men's sports.

It also depends on the discipline. Women's volleyball or football compared to men's, it's obvious. Or running, everybody knows that women are slower. So where it's faster, higher - in football, volleyball, the game is faster, at a more technical level - this sport is considered to be worse. (interview 18)

The quoted statements reveal that men's sports were treated as a model to be followed by women's sports and female athletes. Treating men's sports as a norm generated the respondents' belief that women's sports are inferior.

Seeing women's sports as worse than men's sports resulted mainly from looking at the matter from the 
perspective of physiological differences between women and men.

I think women have less ... even in the case of basketball, you can rarely get excited with women's basketball. Because women have less dynamics, strength, precision. (interview 8 )

The underrepresentation also results from the body build, the physiology, we can't do anything about it. From the fact that a female sprinter will always have a different time than a male sprinter. (interview 3 )

The physiological differences between women and men that result in better outcomes of male contestants were not critically evaluated by the journalists. The lower position of women's sports - resulting in the respondents' opinion about 'the natural difference of the sexes' - was internalized by the journalists and not questioned by them ${ }^{2}$. In their statements, the belief about the higher status of men's sports was not confronted with the social context in which women's sports function. The conviction about worse predispositions of girls and women to play sports - which may result in lesser involvement of the parents, school or instructors and trainers in encouraging girls to train, less money spent on women's sports, or fewer sports sections or clubs willing to train girls - was not discussed by the respondents. Researchers also point to the lack of role models of female athletes, which could have a significant impact on the popularization of women's

\footnotetext{
${ }^{2}$ It is not about questioning gender differences, but about drawing attention to the fact that nowadays the gender difference is often reconstructed into a social difference. The gender difference becomes the basis for perceiving women's sport as inferior, which supports the traditional order of gender as well as male hegemony. This situation is strengthened by constant the comparing of women's and men's results, supporting the impression that women's results are always worse than those of men (Jakubowska 2013:110-113).
}

sports (Jakubowska 2014:171-172). The issue of omitting the gender factor in the assessment of women's sports will be tackled again further in the article.

When arguing in favor of the higher status of men's sports, the interviewed journalists often relied also on the stereotypical view of women's sports, arguing that perceiving women's sports as subordinate is due to the "emotional instability" of female athletes. They justify their opinions with the beliefs of the athletes themselves, their fans or trainers.

Tennis has a slogan: women's tennis. Even the female players admit that emotions play a greater role. There happen to be results such as 6/0 0/6, this doesn't happen, or happens very rarely, in men's tennis. (interview 4)

Women's volleyball is not the same as men's volleyball. There is a reason why they say that only in women's volleyball you can win 2:0 in sets and 20:18. and you still lose 2:3. Unfortunately, it's just the way it is. Women's sport is seen a bit differently. (interview 17)

There is this belief/saying among journalists and contestants that women's sport is so ... I am not talking about athletics but volleyball, basketball, handball ... that it's a completely different discipline. It results from physiology. Women are not that strong, the game is not that fast, dynamic, there are no such blows ... But it's not that a guy says that he can't watch it, but female volleyball players themselves say 'you know, I normally don't watch women's volleyball because tell me, how can you watch it?'. They say that they prefer to watch men's volleyball because there is more dynamics in it. They say it themselves. (interview 3)

The internalization of stereotypical beliefs about femininity, illustrated by the above quotes, made 
the female respondents ignorant of the underrepresentation of women's sports in the media as harmful for female athletes.

\section{The Homogenous Perception of Women's Sports}

The female journalists were also asked about their opinion on the underrepresentation of media coverages of women's sports in the Polish media, as demonstrated in the studies by Dziubiński et al. (2019) and Jakubowska (2013). Most of the interviewees were not surprised with the underrepresentation. At the same time, it appeared from their statements that they do not object to such a situation, treating it as normal.

We need to know the reality and adapt to it. (interview 13)

It has become customary that men's games are treated seriously and women's - less seriously. That's how it is. (interview 11)

The interviews showed that the participants see areas in which women's sports are treated inferior. They mentioned lower funds for broadcasting women's sports, or doing coverages of women's sports only in the case of a big success of female players, and frequent referring to their physical appearance. However, primarily they pointed to the needs of the audience and the popularity of a given discipline. In addition, they emphasized a small number of female sports stars, a smaller number of disciplines in which women compete, and the willingness of male journalists to deal with what is most important in sport, i.e., frequently, men's sports. No doubt, the neoliberal market influences the practices in sports newsrooms, the choice of topics presented, and the amount of information released to the me- dia regarding a given topic. The inseparable links between sports media and economy are emphasized with the terms sport-media complex or medial sport production complex (Rowe 2004:68-79). In addition, in recent years attention has been paid to the deepening precarization of working conditions in journalism (Cohen 2015). Nevertheless, it has been demonstrated that sports journalists still have some space to take autonomous decisions about what is worth presenting to the sports media audience (Knoppers and Elling 2004). Their attitude towards what is newsworthy and to perceiving the status of women's sports is important for the contents of sports media. None of the respondents but one paid attention to the fact that it is difficult to decide to what extent the audience themselves decide which sporting events are worth following the most, and to what extent the media form the audience's tastes by covering specific events. The media are constantly sparking interest in specific disciplines, ignoring others. In addition, they play a significant role in creating sports stars. Of course, nowadays social media help athletes create and control their media images; nevertheless, presence in traditional media is still important. The research participants, however, did not perceive themselves as those who have influence on what information is released to the media and shape the tastes of the audience.

The claim that women compete in fewer disciplines (and fewer events) than men is true. However, in recent years women have won the right to engage in disciplines reserved for men, e.g. women have been allowed to compete in boxing (Olympic Games in 2012) or ski jumping (Olympic Games in 2014). What is more, the number of disciplines they do not compete in is constantly declining. Additionally, more and more women are interested in sports and are doing sports (Lenartowicz, Dziubiński and Jankow- 
ski 2017). Therefore, it can be concluded that women are also becoming an increasingly important part of sports events and their audiences. However, the interviews did not indicate that it was noticed by the journalists.

Some of the participants asked what the researchers meant when using the term "women's sports," because it tended to be incomprehensible. Suggestions appeared that the use of this concept is pointless, since women practically do all disciplines. Other respondents, in turn, asked whether the notion refers only to the disciplines which are exclusively female. Opinions of the female journalists about factors influencing the underrepresentation of women's sports were often contradictory, while their views were not always clear. The requests to explain the concept of "women's sports" may suggest that so far the participants have not thought about gender as a factor determining the position of athletes, especially with sports considered to be 'masculine' and team sports. The statement below shows a lack of systematized beliefs about the reasons for the underrepresentation of women's sports coverages and the possibilities of changing this situation. Such a stance was frequently observed during the interviews. On the one hand, the participants state that women's sports must become more popular among fans in order to appear in the media more often. On the other hand, they claim that the media have to cover women's sports more often in order to stimulate interest in it.

Information is provided according to the needs and interests of the viewer/audience. They write about things that will have the biggest impact and will be most sought-after. It's not surprising that it's mainly information about men's sports, because they are masters. If we want to receive more information about women's sport, it must become more popular among the audience, then more information will be available. People generating information will see a change in trends and will try to meet the demand. Promotion and popularization are needed. More frequent appearance on TV. (interview 15)

\section{The Denial of the Gender Factor in Sports Coverages}

Despite pointing to double standards in reporting women's sports (informing about events regarding women's sport only in the case of a big success, focusing on the physical appearance of female athletes, etc.), the respondents did not advocate reducing the under-representation of women's sports in the media. They did not agree that the under-representation of media coverages of women's sports had something to do with a gender-biased approach to women and women's sports.

I will not express any feminist opinion. Personally I prefer watching men's sports, team sports, and I think that the importance of an event is a determining factor. It's important to choose what will be interesting to fans. I don't think there's too little of women's sports on the radio or on television. It's rather fair (...). Naturally, there will be more of it with time. A lot of women's disciplines will develop, priority will be given to training. There's no reason to provoke anything in an artificial way. There must be a big success, regardless of the discipline. (interview 10)

I would love to tell you that it is not [fair - N.O.], but the problem is that I can't bear women's sports myself. However, it seems natural to me, because the physical build of men is different. They are taller, faster, and stronger, and every sport they do is more visually attractive. Apart from rhythmic gymnastics. In case 
of women, everything is a child-like version of men's sports. It's less spectacular. And this is not a matter of fairness. It cannot be imposed. Even if you dig your heels in and write 50/50, it will not catch on because it's simply less interesting. I can say it as a spectator. I love volleyball, but every women's match I have to watch is a real pain. There's a league in Legionowo, I went to see it twice, but I thought I would not survive it. It's truly deserved that women's sport is less promoted in the media. (interview 7)

The journalists had internalized the perception of women's sports as inferior, which is why their smaller exposure and popularity was not surprising to them. Additionally, the first of the above statements suggests the belief that the change will take place in a 'natural' way based on a greater presence of women in sports and meritocratic factors (success). The quoted journalist does not take into account the cultural meanings attributed to sport (as a male undertaking) and femininity (treated as otherness in sport), which disfavor women's sports and make their marginalization perceived as innocent. What is more, although sometimes the participants claimed that you could promote specific disciplines and topics, and 'sell everything' in the media, they did not see the need to generate more interest in women's sports. When answering a question about whether it would be fair to have more coverages of women's sports, the journalists emphasized factors other than gender.

I don't know if we can talk about injustice here, I think that market rules are decisive here. (interview 4)

It's not a matter of women and men. It's a matter of money. I rebelled against it ardently, but it's so big, it's such a system and such money that you can't... You can either accept it or not. (interview 18)
In addition to what has already been said, the first agents who socialize a person into sport could be of significance. Sixteen of the eighteen female journalists declared that it had been their fathers, grandfathers, brothers, or physical education teachers who encouraged them to become interested in sports. The socialization agents had the possibility to shape the views of the respondents about what is valuable and worth attention in sport. One of the respondents described her socialization into sport in the following way:

It is because of my dad, who is a big fan of all kinds of sports, where he sees our Polish representation in white and red; my boyfriend, who is a total sports freak, and sport is present at home all the time. If it were not for this, I think I wouldn't have such skills to understand sport. This suggests that it's men's influence in my case. (interview 15)

Considering the fact that men usually think of sport as their natural space as well as they choose to be involved in sport more often than women, the significant men in the interviewees' lives could have instilled in them the belief that men's sports set a certain standard and norm. Annemarie Farrell, Janet Fink and Sarah Fields (2011) showed that men had had a great influence on their researched subjects' sport consumption. The influence of men on the indirect sport consumption in the family was evident in various generations, starting from grandfathers and ending with current partners, with whom women watch sports events. The result of this situation may be the creation of the 'male gaze' that is responsible for the higher valuation of men's sports (see: Whiteside and Hardin 2011:125).

The fact that the journalists did not see gender as an important factor behind the reduced exposure of 
women's sports in the media can result from perceiving men's sports as a norm. A higher valuation of men's sport is difficult to recognize due to the difference resulting from physiology and, consequently, better sports results achieved by men. As Honorata Jakubowska states, "Differences, including gender differences - most often taking the form of dichotomy - are not usually neutral but they involve prioritization, the relation of subordination and domination" (Jakubowska 2015:111). The author also thinks that sportspeople are treated as "neuter" exponents of a certain norm or standard in sport, "referring not so much to what is masculine but to what determines the sport as such" (Jakubowska 2015:114).

\section{Discussion and Concluding Remarks}

This study is one of the few conducted outside the Anglo-Saxon context and as such can constitute a significant contribution to the research done so far. The study demonstrates the prejudiced attitude of female journalists to women's sports as well as ignorance regarding the gender perspective when assessing women's sports. Therefore, it confirms the findings of Hardin and Shain (2005; 2006), Claringbould et al. (2004), North (2009), Chambers et al. (2004), or Whiteside and Hardin (2015).

The study participants presented homogeneous opinions about women's sports. They assessed women's sports as subordinate to men's sports. In their opinion, they supported their views with the beliefs of the entire sports environment. They had internalized the belief that men's sports make for a certain norm, to which female athletes must aspire. The fact that sports media devote more space to male athletes was neutralized and ignored by the journalists, and resulted in the belief that the amount of coverages of women's sports in the Polish media is fair and does not require a change or an intervention.

The interviewed female sports journalists did not look at sport through relationships and a certain gender order. They did not perceive sport as an androcentric structure that disfavors women. Moreover, the journalists did not recognize or point to social factors contributing to the belief that sport substantially remains an entertainment and a way of spending leisure time for boys and men predominantly. However, they identified a number of meritocratic factors that are, in their opinion, responsible for the over-representation of men's sports. The belief that it is not gender but, rather, skills, success, and interests of the audience that are important in sport (and the media) makes it extremely difficult to look at sport as an institution that reproduces biological differences into social differences. The prevalent 'gender blindness' caused the journalists to consider any possible activities that could contribute to a greater exposure of women's sports in the media as pointless. Thus, the study presented in this article indicates the limitations of the assumption that a greater professional representation of women will mean the introduction of a critical attitude towards the current media coverages of women's sports. A larger group of female journalists in Polish sports departments would not translate into more frequent coverages of women's sports in the media as well as respectful descriptions of women's sports and female athletes. Instead, this article points to the need to critically examine the discourse of sport, masculinity, and femininity in order to make the gendered structure of sports journalism visible, and to question the currently higher valuation of maleness and masculinity in sport. 
Opinions of female sports journalists about women's sports may be the result of professional socialization, long-established norms and routines in sports journalism and their minority status in the profession. The participants are in the first generation pursuing this profession in Poland. They all declared working in the "masculine environment" to which they had to adapt in order to function in it (Organista, Mazur 2019). There's no organization or association that cares about their interests as a group, or female mentors that could be an alternative to male sports journalists introducing the interviewed journalists into the profession. Moreover, the established beliefs in journalism about what is most often desirable in the media (hard news or men's sports) or the hierarchy of values (objectivity, independence, neutrality) may be the reason why female journalists distance themselves from women's sports. Attempts to introduce more information about women's sports could be perceived as biased. As North (2009) pointed out, neither male nor female journalists recognize that the culture of journalism remains based on male values. In turn, understanding femininity as opposing rationality and objectivity may be the cause why female journalists distance themselves from their gender identity in need to be perceived as professionals (Chambers et al. 2004; Hardin and Shain 2006).

Referring the obtained research results to a broader cultural context, it should be noted that Poland remains a patriarchal country where women's rights are particularly questioned. In addition, the Polish feminist environment does not consider sports as an important area for maintaining gender equality (Jakubowska 2014:83-89). As Jakubowska wrote: “Issues of amateur or professional sports, as far as I am concern, are not dealt with the feminist activists/ organizations in Poland. Those issues are absent in the scientific literature embracing gender perspective as well as in the activities of such organization, which distinguishes Poland from many countries, for example USA, Canada, UK or Nordic countries" (Jakubowska 2014:85-86). Struggling with numerous problems, Polish feminist organizations and activists remain active in areas where the rights of Polish women are violated in the most vivid way (e.g. reproductive rights, gender-based violence), which is why sport is rather outside their area of operation. As Jakubowska (2014:69) points out, it is also important that before the year 1989 the communist authorities in Poland had supported the idea of gender equality. The achievements of Polish female athletes (like: Irena Szewińska, Teresa Ciepły, Barbara Sobotta or Halina Górecka) were promoted in the hope that it would improve Poland's image on the international arena. After the change of the political system - and as a sign of renouncing the communist rule - women's rights were no longer considered as an important demand. Also, the growing influence of the Catholic Church promoting the so-called 'values of a traditional family' - combined with the right-wing parties and organizations' agendas - has made the feminist paradigm marginalized (Grabowska 2014; Korolczuk and Graff 2018). The influence of the Catholic Church results from the significant role it had played in the battle against the communist state; this has allowed the Church authorities to influence public discourse in Poland till the present day. The Church-driven war against the so-called 'genderism' or 'gender ideology' remains the expression of such an attitude; the actions of representatives of the Catholic Church and right-wing circles aim at presenting organizations and people trying to introduce gender-mainstreaming policies in Poland as the opponents of the Polish national interest (Graff 2014). All these factors make researchers pay attention to the fact that Poland is undergo- 
ing another wave of anti-feminism (Szelewa 2014). In addition, the cult of the so-called 'Polish Mother' remains important in Poland, strengthening the belief that motherhood is the most important task for women. Maintaining the traditional role of a woman as mother and the guardian of the family also hinders the emancipation of women and seeking equality in professional life. The above-mentioned current state of perceiving the importance of gender equality in Poland would explain the negative beliefs of the researched female journalists about women's sports. The fact that sport is not considered as an important arena of the struggle for women's rights - and the general marginalization of equal-

\section{References}

Angelini, James R., Paul J. MacAuthur, and Andrew C. Billings. 2012. "What's the gendered story? Vancouver's prime time Olympic glory on NBC." Journal of Broadcasting \& Electronic Media 56:261-279.

Billings, Andrew C. and Brittany D. Young. 2015. “Comparing flagship news programs: Women's sport coverage in ESPN's SportsCenter and FOX Sports 1's FOX Sports Live." Electronic News 9(1):3-16.

Bissell, Kimberly L. and Andrea M. Duke. 2007. “Bump, set, spike: An analysis of commentary and camera angles of women's beach volleyball during the 2004 summer Olympics." Journal of Promotion Management 13(1-2):35-53.

Boyle, Raymond.2006. Sports journalism: Context and issues. New York: Sage.

Bruce, Toni. 2013. "Reflections on communication and sport: On women and femininities." Communication $\mathcal{E}$ Sport 1(1-2):125-137.

Bruce, Toni. 2016. "New rules for new times: Sportswomen and media representation in the third wave." Sex Roles 74(7-8):361-376. ity-related beliefs - does not allow for looking at sport as a field of gender relations, and for promoting women's sports.

Undoubtedly, relying only on individual in-depth interviews is a limitation of this study. Although the method made it possible to present the views of female journalists in detail, it would be worth supplementing it with an ethnographic research conducted in sports departments. Such research could offer more knowledge about the process of gatekeeping, the perception of what is newsworthy in sports media, and the gendering of the process of constructing information in the media.

de Bruin, Marjan and Karen Ross. 2004. "Beyond the body count." Pp. vii-xii in Gender and newsroom cultures: Industries at work edited by Marjan de Bruin and Karen Ross. Cresskill, New York: Hampton Press.

Chambers, Deborah, Linda Steiner, and Fleming Carole (eds.). 2004. Women and journalism. London: Routledge.

Claringbould, Inge, Annelies Knoppers, and Agnes Elling. 2004. "Exclusionary practices in sport journalism." Sex Roles 51(11-12):709-718.

Cohen, Nicole S. 2015. "Cultural Work as a Site of Struggle: Freelancers and Exploitation." TripleC 10(2):141-155.

Cooky, Cheryl, Michael A. Messner, and Michaela Musto. 2015. “'It's dude time!': A quarter century of excluding women's sports in televised news and highlights shows." Communication $\mathcal{E}$ Sport 3:261-287.

Crolley, Liz and Elena Teso. 2007. “Gendered narratives in Spain. The Representation of Female Athletes in Marca and El País." International Review for The Sociology of Sport 42(2):149-166. 
Creedon, Pamela. 1998. “Women, Sport, and Media Institutions: Issues in Sport Journalism and

Marketing." Pp. 88-99 in MediaSport, edited by Lawrence Wenner. London: Routledge.

Dziubiński, Zbigniew, Natalia Organista, and Zuzanna Mazur. 2019. "Still marginalised: Gender inequalities in the largest Polish daily's sports coverage." Communications: European Journal of Communication Studies 44(1):33-57.

Eagleman, Andrea. 2015. "Constructing gender differences: newspaper portrayals of male and female gymnasts at the 2012 Olympic Games." Sport in Society: Cultures, Commerce, Media, Politics 18:234-247.

Farrell, Annemarie, Janet S. Fink, and Sarah Fields. 2011. “Women's sport spectatorship: An exploration of men's influence." Journal of Sport Management 25(3):190-201.

Ferguson, Marjorie. 1990. "Images of power and the feminist fallacy." Critical Studies in Mass Communication 7:215-230.

Fink, Janet S. and Linda J. Kensicki. 2002. "An imperceptible difference: Visual and textual constructions of femininity in Sports Illustrated and Sports Illustrated for Women." Mass Communication \& Society 5(3):317-339.

Franks, Suzanne and Deirdre O’Neill. 2016. “Women reporting sport: Still a man's game?" Journalism 17(4):474-492.

Godoy-Pressland, Amy. 2014. "'Nothing to report': a semi-longitudinal investigation of the print media coverage of sportswomen in British Sunday newspapers." Media, Culture E Society 36(5):595-609.

GMMP. 2015a. Poland. Retrieved November 15, 2019 (http://cdn. agilitycms.com/who-makes-the-news/Imported/reports_2015/ national/Poland.pdf).

GMMP. 2015b. Retrieved November 15, 2019 (http://cdn.agilitycms.com/who-makes-the-news/Imported/reports_2015/global/ gmmp_global_report_en.pdf).

GMMP. 2015c. Europe. Retrieved November 15, 2019 (http://cdn. agilitycms.com/who-makes-the-news/Imported/reports_2015/ regional/Europe.pdf).

Grabowska, Magdalena. 2014. “Cultural War or 'Business as Usual'? Recent Instances, and the Historical Origins, of a 'Backlash' against Women's and Sexual Rights in Poland." Pp.
54-64 in Anti-Gender Movements on the Rise? Strategising for Gender Equality in Central and Eastern Europe, edited by the Heinrich Böll Foundation. Berlin: Heinrich Böll Foundation.

Graff, Agnieszka. 2014. "Report from the Gender Trenches: War against 'Genderism' in Poland." European Journal of Women's Studies 21(4):431-435.

Greer, Jennifer D., Marie Hardin, and Casey Homan. 2009. "'Naturally' less exciting? Visual production of men's and women's track and field coverage during the 2004 Olympics." Journal of Broadcasting and Electronic Media 53:173-189.

Hardin, Marie and Stacie Shain. 2005. "Strength in numbers? The experiences and attitudes of women in sports media careers." Journalism \& Mass Communication Quarterly 82(4):804-819.

Hardin, Marie and Stacie Shain. 2006. "“Feeling much smaller than you know you are': The fragmented professional identity of female sports journalists." Critical Studies in Media Communication 23(4):322-338.

Horky, Thomas and Jörg-Uwe Nieland. 2011. International Sport Press Survey 2011. Retrieved January 2, 2015 (https://www.playthegame.org/fileadmin/image/PTG2011/Presentation/PTG_ Nieland-Horky_ISPS_2011_3.10.2011_final.pdf).

Jakubowska, Honorata. 2013. "Płeć (w) fizjologii sportu." Kultura Wspótczesna 3(78):105-117.

Jakubowska, Honorata. 2014. Gra ciałem. Praktyki i dyskursy różnicowania ptci w sporcie [The Game of the Body. The Practices and Discourses of Gender Differentation in Sport]. Warsaw: PWN.

Jakubowska, Honorata. 2015. "Are women still the 'other sex': gender and sport in the Polish mass media." Sport in Society: Cultures, Commerce, Media, Politics 18:168-185.

Korolczuk, Elżbieta and Agnieszka Graff. 2018. “Gender as ‘Ebola from Brussels': The Anticolonial Frame and the Rise of Illiberal Populism." Signs: Journal of Women in Culture and Society 43(4):797-821.

Kluczyńska, Urszula. 2011. “Konstruowanie relacji między rodzajami w sporcie. Analiza telewizyjnych wiadomości sportowych." Pp. 383-400 in Kalejdoskop genderowy. W drodze do poznania ptci społeczno - kulturowej w Polsce, edited by Krystyna Slany, Beata Kowalska, Magdalena Ślusarczyk. Cracow: Wydawnictwo UJ. 
Knoppers, Annelies and Agnes Elling. 2004. "“We Do Not Engage in Promotional Journalism' Discursive Strategies Used by Sport Journalists to Describe the Selection Process." International Review for the Sociology of Sport 39(1):57-73.

Lapchick, Richard. 2008. The 2008 racial and gender report card of Associated Press sports editors. Retrieved February 2, 2018 (www. tidesport.org/RGRC/2008/2008_APSE_RGRC_Press_Release.pdf).

Lenartowicz, Michał, Zbigniew Dziubiński, and Krzysztof Jankowski. 2017. „Aktywni Polacy: Dwie dekady uczestnictwa w sporcie i rekreacji ruchowej. Próba wyjaśnienia zmian." Kultura i Społeczeństwo 2:196-210.

Nastasia, Diana Iulia and Sorin Nastasia. 2013. "Poland: Women Journalists and 'The Polish Mother' Mentality." Pp. 151-163 in The Palgrave International Handbook of Women and Journalism, edited by Carolyn Byerly. New York: Palgrave Macmillan.

North, Louise. 2009. “Gendered Experiences of Industry Change and the Effects of Neoliberalism." Journalism Studies 10(4):506-521.

North, Louise. 2016. "The Gender of 'soft' and 'hard' news: Female journalists' views on gendered story allocations." Journalism Studies 17(3):356-373.

O'Neill, Deirdre and Matt Mulready. 2015. “The Invisible Woman? A comparative study of women's sports coverage in the UK national press before and after the 2012 Olympic Games." Journalism Practice 9(5):651-668.

Organista, Natalia and Zuzanna Mazur. 2019. “'You either stop reacting or you don't survive. There's no other way': the work experiences of Polish women sports journalists." Feminist Media Studies:1-18.

Rowe, David. 2004. Sport, culture and the media. Buckingham: Open University Press.

Sherry, Emma, Angela Osborne, and Metthew Nicholson. 2016. "Images of sports women: A review." Sex Roles 74(7-8):299-309.
Schmidt, Hans C. 2018. "Forgotten Athletes and Token Reporters: Analyzing the Gender Bias in Sports Journalism." Atlantic Journal of Communication 26(1):59-74.

Schoch, Lucie and Fabien Ohl. 2011. "Women sports journalists in Switzerland: Between assignment and negotiation of roles." Sociology of Sport Journal 28(2):189-208.

Steiner, Linda. 2012. "Failed theories: Explaining gender difference in journalism." Review of Communication 12(3):201-223.

Strong, Cathy and Grant Hannis. 2007. "The Visibility of Female Journalists at Australian and New Zealand Newspapers: the Good News and the Bad News." Australian Journalism Review 29(1):115-126.

Szelewa, Dorota. 2014. "The Second Wave of Anti-Feminism? Post-Crisis Maternalist Policies and the Attack on the Concept of Gender in Poland." Gender, rovné príležitosti, výzkum 15(2):33-47.

Vincent, John et al. 2007. “Analysing the print media coverage of professional tennis players: British newspaper narratives about female competitors in the Wimbledon Championships." International Journal of Sport Management and Marketing 2:281-300.

Turner, Jacob S. 2014. “A longitudinal content analysis of gender and ethnicity portrayals on ESPN's SportsCenter from 1999 to 2009." Communication E Sport 2(4):303-327.

Wensing, Emma H. and Toni Bruce. 2003. “Bending the rules: Media representations of gender during an international sporting event." International review for the sociology of sport 38(4):387396.

Whiteside, Erin and Marie Hardin. 2011. “Women (not) watching women: Leisure time, television, and implications for televised coverage of women's sports." Communication, Culture $\mathcal{E}$ Critique 4(2):122-143.

Whiteside, Erin and Marie Hardin. 2015. "The Glass Ceiling and Beyond." Pp. 146-154 Routledge Handbook of Sport Communication, edited by Paul Pedersen. New York: Routledge.

\section{Citation}

Organista, Natalia and Zuzanna Mazur. 2020. “Guardians of the Hegemonic Structure of Sports? Women's Sports as Perceived by Polish Female Sports Journalists.” Przeglad Socjologii Jakościowej 16(1):48-64. Retrieved Month, Year (www.przegladsocjologiijakosciowej.org). DOI: http://dx.doi.org/10.18778/1733-8069.16.1.04 


\title{
Strażniczki hegemonicznej struktury sportu? Postrzeganie sportu kobiet przez polskie dziennikarki sportowe
}

\begin{abstract}
Abstrakt: Niedoreprezentowanie medialnych przekazów o sporcie kobiet jest od lat wskazywanym fenomenem dotyczącym również Polski. Jako jedną z możliwych przyczyn mniej licznych informacji o sporcie kobiet wskazuje się niekiedy małą liczbę dziennikarek sportowych. W związku z brakiem polskich badań dziennikarek sportowych postanowiono przeanalizować ich przekonania na temat sportu kobiet oraz niedoreprezentowania przekazów medialnych o sporcie kobiet w polskich mediach. Badanie wykazało, iż dziennikarki sportowe postrzegają sport kobiet jako gorszy niż sport mężczyzn i nie popierają zwiększenia ilości informacji o sporcie kobiet. Autorka wskazuje na socjalizację do sportu i zawodową badanych, ich mniejszościowy status w zawodzie oraz postrzeganie męskości, kobiecości i profesjonalizmu w dziennikarstwie jako możliwe przyczyny postrzegania przez badane sportu kobiet.
\end{abstract}

Słowa kluczowe: dziennikarstwo sportowe, dziennikarki sportowe, sport kobiet 